\title{
LA INMIGRACIÓN COLOMBIANA EN EL CINE RECIENTE
}

Por:

Manuel Silva Rodríguez

Profesor asistente

Escuela de Comunicación Social

Facultad de Artes Integradas

Universidad del Valle

manuel.silva@correounivalle.edu.co

\section{Resumen:}

Este texto presenta resultados de una investigación sobre películas de reciente factura, cuya temática principal se relaciona con la vida de personajes colombianos en la inmigración y con la presencia de personajes extranjeros en Colombia. Desde la perspectiva de la imagología, el texto expone y reflexiona sobre algunas de las imágenes identitarias de los colombianos en la inmigración construidas por los filmes analizados.

\section{Palabras clave:}

alteridad, cine colombiano, estereotipos, extranjeros, globalización, identidad, imagen, imagología, inmigración, narcotráfico, violencia. 


\section{Introducción}

Este artículo se deriva de la investigación Imágenes del otro: Representaciones de la identidad colombiana ante otras culturas en producciones y coproducciones cinematográficas colombianas de ficción realizadas entre 1999 y $2009^{1}$. La investigación tuvo como objetivos analizar e interpretar cómo se ha representado la identidad de los colombianos en sus experiencias y relaciones en otros países o en el propio con extranjeros. Al mismo tiempo, procuró observar cómo han sido representados los extranjeros. Es decir, la investigación se propuso establecer cuáles son las imágenes de los colombianos y de los «otros» presentes en un grupo de filmes de ficción.

El artículo, sin embargo, sólo expone brevemente algunos conceptos que sirvieron de marco conceptual a la investigación y algunos resultados que tienen que ver con la representación de la vida de colombianos en otros países ${ }^{2}$. El texto presenta, entonces, en primer lugar algunas consideraciones teóricas acerca de conceptos como los de identidad, alteridad y extranjero. En segundo lugar, expone el enfoque metodológico seguido en la lectura de las películas y la conformación del corpus analizado. Por último, el texto presenta algunas de las imágenes frecuentes en los filmes y varias conclusiones derivadas del análisis.

\section{Presupuestos teóricos}

\section{1. ¿De qué hablamos cuando hablamos de identidad?}

Siguiendo algunos planteamientos de Stuart Hall [1996], este texto adopta una posición teórica que hoy es de uso corriente: el concepto de identidad ha sido despojado de sentidos y valores esencialistas. En efecto, haciendo referencia al método utilizado por la deconstrucción, Hall señala que ésta, a diferencia de otras corrientes críticas, no sustituyó por otro el término «identidad», sino que lo sometió a «borradura». Ello no quiere decir que la cuestión de la identidad designe ahora un campo de problemas totalmente ajenos a los de antes. Lo que plantea, más bien, es mirarlos desde otra óptica: es "una idea que no puede usarse a la vieja usanza, pero sin la cual ciertas cuestiones clave no pueden pensarse en absoluto" [Hall, 1996: 14].

Y si bien la perspectiva que abrió la deconstrucción de tipo derrideana propició una inversión del contenido del concepto de «identidad», la perspectiva abierta por Foucault sobre el descentramiento del sujeto y la puesta en evidencia de su inscripción en prácticas discursivas descubrió otro camino. Hall señala que desde este punto de vista la cuestión de la identidad vino a ser pensada como "el proceso de sujeción a las prácticas discursivas" [1996: 15], o sea, como la identificación con uno u otro discurso ${ }^{3}$. Aunque, según Hall, al igual que el concepto de identidad el de identificación no está exento de dificultades, éste es preferible que aquél porque hace evidente que la identidad es la identificación con una o varias prácticas discursivas. Esto es, la configuración de un sujeto histórico mediante su integración al tipo de orden que supone un determinado discurso.

Establecer que la «identificación con» y en general la configuración de la identidad acontecen en el ámbito discursivo es reconocer que estos procesos ocurren en el territorio del lenguaje. «Identificarse con» $\mathrm{o}$ «identificar a otro con» es vincular una forma de existencia con predicados, imágenes y símbolos. "Las identidades, en consecuencia, se construyen dentro de la representación y no fuera de ella" [Hall, 1996: 17]. «Identificarse con», entonces, es construir una representación de un sujeto, ya sea de sí mismo o de otro. Dicho de otro modo: la identidad viene a ser entendida como una representación que se cree y se acepta. La expresión más extrema de este concepto es que la identidad, en cuanto a su nivel ontológico, tiene lugar en la imaginación. Empero, aceptar este postulado no significa restar valor o potencial a la identidad en el dominio práctico:

la naturaleza necesariamente ficcional de este proceso no socaba en modo alguno su efectividad discursiva, material o política, aun cuando la pertenencia, la «sutura en el relato» a través de la cual surgen las identidades resida, en parte, en lo imaginario (así como en lo simbólico) y, por lo tanto, siempre se construya en parte en la fantasía o, al menos, dentro de un campo fantasmático [Hall, 1996: 18] . ${ }^{4}$ 
Este modo de concebir el concepto descubre que si las prácticas discursivas son históricas, contingentes y cambiantes, la identificación con ellas también lo será. En cuanto los discursos se transforman, también pueden cambiar las identificaciones. Este enfoque ha permitido pensar la identidad como una situación transitoria, como una cualidad que no está definida de una vez y para siempre. Por este motivo, haciendo referencia a la identidad individual, Zygmunt Bauman sostiene que "los individuos «no tienen una identidad», sino más bien deben enfrentarse con la larga, penosa e inacabada tarea de la identificación" [1999: 146]. Lo mismo cabe decir para las colectividades: los grupos o comunidades no tienen una identidad suprahistórica ${ }^{5}$. Por eso hoy resulta problemático hablar de algo como «la colombianidad», como si existiera una esencia que definiera a los colombianos.

Por otra parte, el acto de «identificarse con» tiene implícito un sentido negativo: «identificarse con» es el anverso de «diferenciarse de», de «no identificarse con». Esta diferenciación otorgará relieve a ese o eso que no se es, a lo que no se parece a la idea que de sí se forma un sujeto, a lo diferente, al «otro», a la alteridad. Así, adoptar una identidad puede ser a la vez un proyecto - si se persevera en ella, si se quiere conservarla — y un proceso de exclusión. «Identificarse con» es establecer un adentro y un afuera: "Las identidades se construyen a través de la diferencia, no al margen de ella. [...] A lo largo de sus trayectorias, las identidades pueden funcionar como puntos de identificación y adhesión sólo debido a su capacidad de excluir, de omitir, de dejar «afuera»" [Hall, 1996: 18]. Este hecho es significativo cuando se trata de grupos, porque si bien un colectivo u otro se sitúa en una misma constelación histórica cada uno ocupa en los campos social, cultural y político una posición en relación con el otro ${ }^{6}$.

Pero el «otro» no cuenta sólo como instancia respecto de la cual un sujeto ocupa una posición. El otro también cuenta porque, como el espejo lacaniano, nos devuelve una imagen nuestra. Resultado de este movimiento es que la representación que construimos de sí mismos implica la imagen que «ellos», los «otros», se forjan de nosotros. Como asegura Fernando Aínsa, "la «representación» que una sociedad se hace de sí misma no basta para configurar su identidad. Es necesario - y muchas veces en forma abiertamente contradictoria - integrar esta representación con la idea que los «demás», es decir, los integrantes de «otros grupos culturales», se hacen de «esa» identidad" [1986: 30].

Entonces, ¿cómo nos ve el otro?, ¿qué dice de nosotros?, ¿con qué nos identifica?, ¿qué somos para él?, ¿desde dónde nos mira? De acuerdo con el otro en el que nos miremos tendremos una u otra imagen nuestra. Por eso, como destaca Aínsa, la relación con el otro puede ser contradictoria. Incluso, antes que caracterizarse por la armonía a la relación con el otro la marca la confrontación. La imagen de nosotros que el otro nos devuelve pocas veces nos complace, no siempre corresponde con nuestro concepto de sí.
Además de la alteridad, en la representación que construimos de nosotros también cuentan la memoria y la historia. En la configuración de la identidad, ellas nos dan un marco, nos sitúan en relación con un camino que se va transitando. Aquí se advierte el sentido de la afirmación de Hall, según la cual las identidades "se relacionan tanto con la invención de la tradición como con la tradición misma, y nos obligan a leerla no como una reiteración incesante sino como «lo mismo que cambia»: no el presunto retorno a las raíces sino una aceptación de nuestros «derroteros»" [1996:18]. En la relación entre la construcción de la identidad y el pasado no se trata, pues, de ser fiel a una historia estática, a la imagen de un pasado original y originario, sino de situarnos en una trayectoria que, siendo la misma, se ve diferente desde cada nuevo punto del camino.

Y es en este punto donde el cine, como otras producciones culturales, halla un lugar. La memoria y la historia se construyen con diferentes recursos y medios. En el mundo práctico las personas configuran la memoria social y entran en relación con la historia a través de diversas mediaciones. Así, aceptar que "las identidades se construyen dentro del discurso y no fuera de él” [Hall, 1996: 18], que residen en la imaginación, obliga a considerar que la identidad, como discurso, necesita mostrarse. Como señala Aínsa, "los pueblos, como los individuos, necesitan una «cristalización» del concepto para poder representarse a sí mismos y ante los demás" [1986: 29]. Y el cine, entre otros, es un lugar donde cristaliza ese concepto.

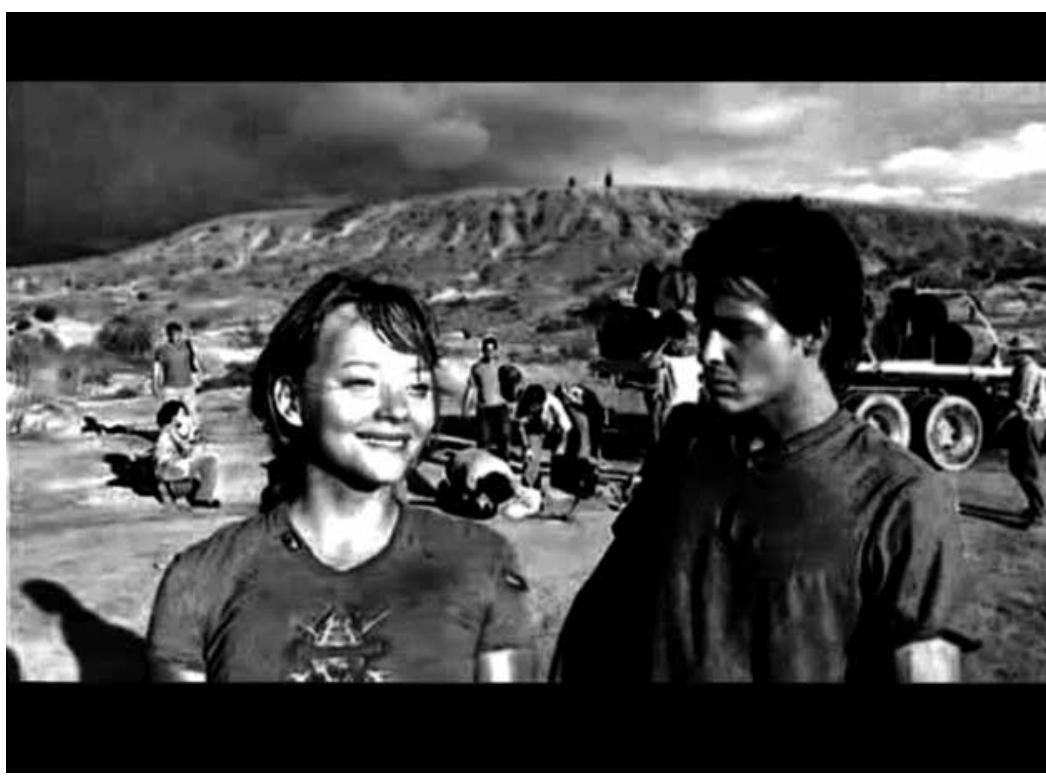




\subsection{El extranjero, el otro}

En el contexto de los flujos de personas y de los cambios sociales y culturales anejos a la globalización, el extranjero es una de las figuras que ha cobrado gran relevancia social y teórica. El extranjero, su imagen, es actualmente una de las formas de alteridad que más incide en la configuración de los discursos identitarios tanto para las personas nativas de un país como para los inmigrantes: "El concepto de extranjería, de otredad, sólo se explica a partir de la existencia de una figura opuesta: la identidad" [Blanck-Cereijido, Yankelevich, 2003: 14]. No obstante, el aumento de las migraciones ha llevado a que, en el movimiento de afirmación de lo «propio» o «interno» y de introducción de lo «ajeno» o «externo», los extranjeros generen diversos tipos de reacciones: desde las políticas y las prácticas que abogan por la «integración» y el multiculturalismo, hasta posiciones opuestas que defienden los nacionalismos más extremos y el racismo so capa de proteger los derechos civiles y económicos de los ciudadanos nacidos en determinado país.

Estas actitudes, sin embargo, no son nuevas. En una aproximación a la historia del término, Blanck-Cereijido y Yankelevich explican que la "palabra extranjero contiene la raíz griega xénos y su enunciado expresa el desprecio y extrañeza que suscita lo que se considera extraño, ajeno, bárbaro, indeseable, aunque algunas veces el extraño pueda ser amado y admirado" [2003: 22]. Estos autores, al igual que Sennett [1978], Bauman [1997, 2001a], entre otros, cuando analizan las reacciones negativas que desencadena la presencia de los extranjeros en un territorio remiten al sentimiento de amenaza que el extraño desencadena en la comunidad. En efecto, en estos casos el extranjero es visto

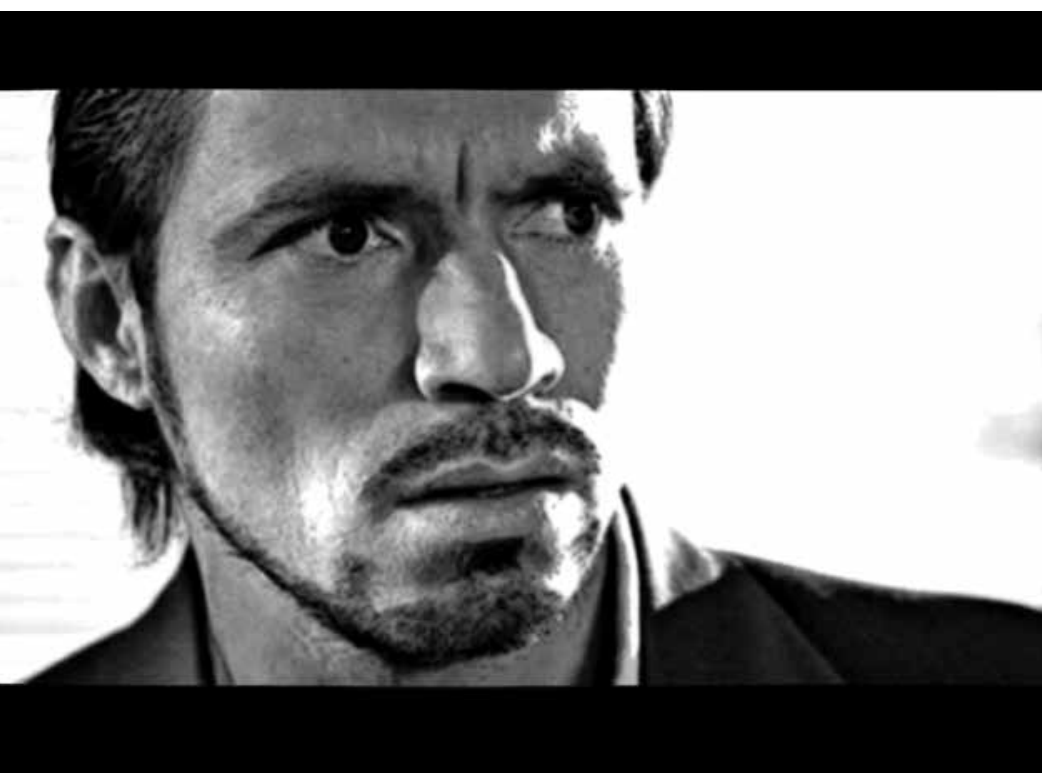

como un agente perturbador, como una presencia que desestabiliza el orden y los sentimientos de familiaridad y seguridad despertados por la pertenencia a una comunidad. El extraño, como dice Bauman, resulta impredecible: "Extraños significa falta de claridad, no se puede estar seguro de lo que harán, de cómo reaccionarán a nuestros actos" [2001a: 104].

Desde este punto de vista, el rechazo y el señalamiento del extranjero serían una manifestación de un sentimiento de temor experimentado frente a aquello que rompe la imagen unitaria de la comunidad: "La creación de otro o la depositación de ciertos caracteres en el otro proviene de la necesidad de proteger la coherencia de la propia imagen" [Blanck-Cereijido, Yankelevich, 2003: 28]. De ahí que estos autores sostengan que "[e]n el fondo, [el término extranjero] responde a una necesidad de identificación, una catalogación que trata de explicar o cuestionar aquello que por su naturaleza diverge de los usos de una comunidad. Con ello surge la figura del otro, a través del cual se filtra nuestra propia identidad" [2003: 13].

Ahora bien, la actitud adoptada frente al extraño no es necesariamente la exclusión. Cuando analiza la presencia de los extranjeros en las sociedades del capitalismo avanzado bajo la figura del extraño, Zygmunt Bauman [2001a: 99-112] recuerda que ante esta forma de alteridad siguen vigentes conductas como la «integración» a través de la reducción del otro a ser útil o exótico. O la de eludir, mantener a una prudente distancia a esos otros que pueden resultar incómodos. Bauman sostiene que "mientras se mantenga la libertad de movimiento y el «poder de evitación», la presencia de extraños no constriñe, irrita ni confunde, mientras las oportunidades de experiencias variadas y apasionantes que ofrece dicha presencia sean bien recibidas y se goce de ellas" [Bauman, 2001a: 106].

No se trata sólo de la reducción de los extranjeros a ocuparse de los oficios que los naturales de un país no desean realizar. Al extraño se le puede permitir acercarse mientras, inserto en el circuito del consumo, sea proveedor de experiencias seductoras. Así, «integrados» al sistema económico "los extraños son personas a las que uno paga por los servicios prestados y por el derecho a prescindir de sus servicios una vez que ya no aportan placer. [...] En esa vida, los extraños son proveedores de placeres" [Bauman, 2001a: 106-107].

Este modo de clasificar a los extranjeros, de fijarles un lugar y un uso de acuerdo con su origen, es una concreción de los prejuicios. Desde la sicología social, Blanck-Cereijido y Yankelevich señalan la relación que puede existir entre el prejuicio colectivo como una forma de manifestarse en la sociedad el narcisismo individual. Es decir, como una forma de mostrarse el ensimismamiento de un grupo: "En el plano social, el narcisismo es sustituido por los prejuicios, que son «aquello que hace que uno se ignore a sí mismo» como grupo" [2003: 24] . 


\section{Enfoque metodológico}

Este trabajo sigue la orientación de la imagología, una línea de investigación que pregunta por las imágenes con las cuales son representados los extranjeros, entendidos como una forma de alteridad, en diversos productos culturales. En principio, la imagología se presentaba como la indagación realizada en torno a la construcción de imágenes y estereotipos ${ }^{8}$ sobre un país o una cultura en una literatura nacional. Como lo precisa Nora Moll,

por imagología se entiende, pues, el estudio de las imágenes, de los prejuicios, de los clichés, de los estereotipos y, en general, de las opiniones sobre otros pueblos y culturas que la literatura transmite, desde el convencimiento de que estas images, tal y como se definen comúnmente, tienen una importancia que va más allá del puro dato [...]. El objetivo principal de las investigaciones imagológicas es el de revelar el valor ideológico y político que puedan tener ciertos aspectos de una obra [...] precisamente porque en ellos se condensan las ideas que un autor comparte con el medio social y cultural en que vive [2002: 349].

Los estudios culturales han encontrado en esta línea de investigación un dominio teórico y metodológico que han ampliado, trasladándolo, como se hace aquí, del campo de la literatura al de producciones culturales como el cine ${ }^{9}$.

Para establecer las imágenes, entonces, la lectura del material fílmico se basó en la siguiente matriz de análisis:

- Espacio en el que transcurre la historia

- Tiempo histórico en el que se sitúa la historia

- Núcleos narrativos

- Actividades a las que se dedican los personajes

- Caracterización de personajes masculinos

- Caracterización de personajes femeninos

- Uso del lenguaje por parte de los personajes

- Opiniones de personajes colombianos sobre personajes de otras nacionalidades

- Opiniones de personajes colombianos sobre sí mismos

- Opiniones de personajes de otras nacionalidades sobre personajes colombianos

- Presencia de símbolos patrios y culturales

- Géneros y estrategias narrativas de las películas

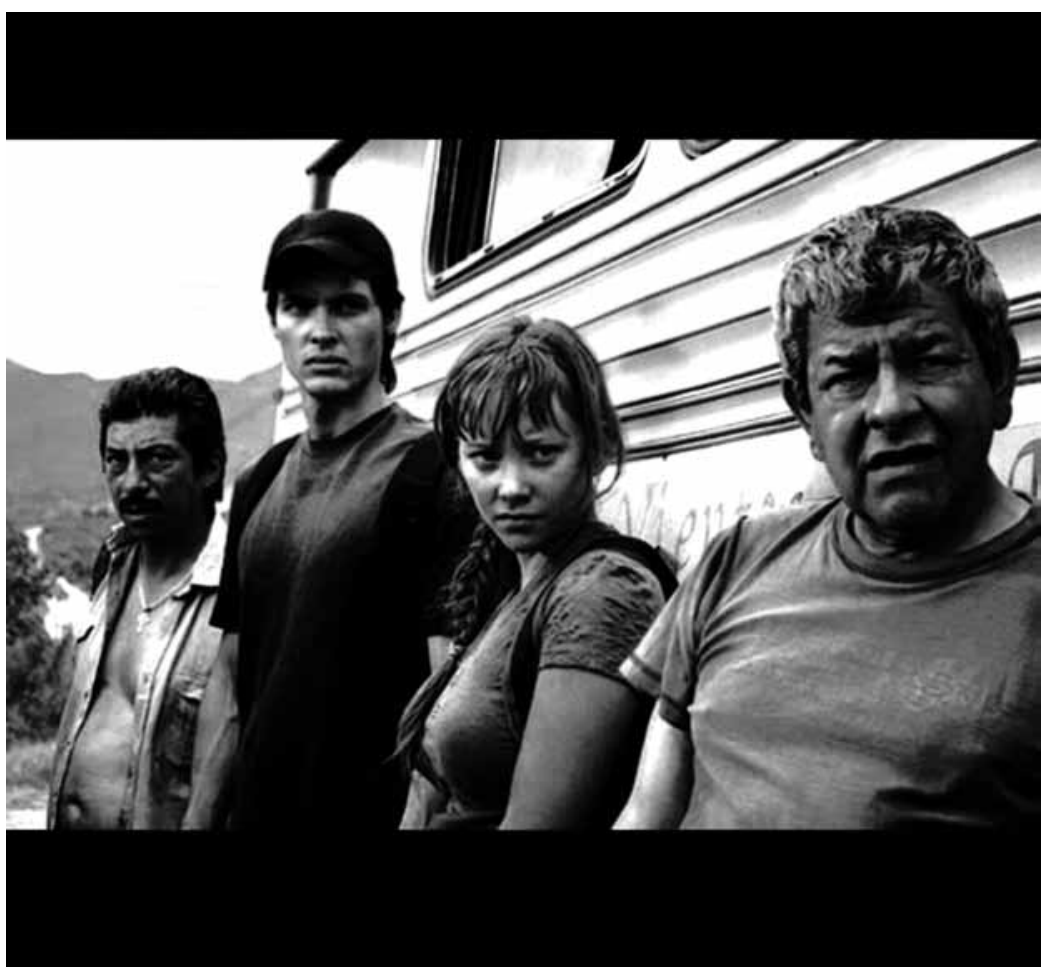

\section{El corpus}

La conformación del corpus se guió por diversos criterios. El criterio temporal definió abordar películas realizadas o estrenadas entre los años 1999 y 2009. Se seleccionaron filmes de reciente

factura y cuyas historias transcurren en el inicio del siglo XXI. La pertinencia temática se basó en que las películas localicen a personajes colombianos en otro país, que sitúen a personajes extranjeros en Colombia o que de algún modo aborden el tema de la inmigración. También se tuvo en cuenta la presencia de recursos colombianos, tales como la intervención de actores, de espacios físicos o a la de capital colombiano o de algún respaldo institucional proveniente de Colombia. Con estos últimos criterios se quiso identificar los discursos que han recibido apoyo del sector público.

El corpus de la investigación lo constituyeron:

- $\quad$ El séptimo cielo (Juan Fischer, 1999)

- María llena eres de gracia (Joshua Marston, 2004)

- Colombianos, un acto de fe (Carlos Fernández, 2004)

- El colombian dream (Felipe Aljure, 2006)

- $\quad$ El trato (Francisco Norden, 2006)

- Paraíso travel (Simón Brand, 2008)

- Dr. alemán (Tom Schreiber, 2008) ${ }^{10}$

- El arriero (Guillermo Calle, 2009) 


\section{Algunas imágenes de la inmigración}

\subsection{Países y motivos para inmigrantes}

En las películas analizadas la vida de los colombianos se desarrolla o se proyecta en Estados Unidos (María llena eres de gracia, Paraíso travel, El séptimo cielo, El trato, El colombian dream, Colombianos, un acto de fe), España (El arriero), Inglaterra (El trato), Canadá (Colombianos, un acto de fe) y Argentina (El trato). Estos países son, pues, escenarios alternativos a Colombia, son figuras de la alteridad frente a la cual, según los filmes, los colombianos miran su país ${ }^{11}$. En las películas, la construcción imaginaria de cada uno de estos países como figuras de la alteridad se funda en idealizaciones, en relatos fragmentarios o en rumores. En María llena eres de gracia, por ejemplo, la visión imaginada más explícita de Estados Unidos la encontramos cuando María pregunta a Lucy, una de las mulas que hacen el viaje con ella, “¿cómo es eso por allá?" Sin vacilar, Lucy responde: "Eso... es demasiado perfecto. Todo es recto”.Y en Paraíso travel Reina, señalando una fotografía de Nueva York, le dice a Marlon "mirá cómo se pone eso allá todo bonito con la nieve, en vez de ese barrial tan hijueputa que se arma acá cada vez que llueve”.

En las películas, los países alternativos a Colombia son seleccionados por los personajes en función de lo que creen que ofrecen sus economías. En un mundo globalizado, se deduce de los filmes, la economía es el factor principal sobre el cual se instauran relaciones de alteridad. Los «otros» son países a los cuales se atribuye una economía mejor y un mercado laboral más fuerte: todos los inmigrantes de Nueva York permanecen allí por el trabajo, en El trato Rosalba vive en Londres mientras tiene una ocupación, en Colombianos, un acto de fe los jubilados se van a Estados Unidos en procura de mejor vida y Juan se va a Canadá en busca de un empleo, en El colombian dream a Lola le niegan el visado a Estados Unidos y decide realizar su propio dream en Colombia: abre un bar donde circulan el dinero y las drogas. Y cuando no es así, es porque otro país es visto como un mercado de consumidores de droga: España en El arriero, Estados Unidos en El trato y en María llena eres de gracia y Argentina también en El trato.

\subsection{De lo imaginado a lo vivido}

Cuando se hace tránsito del «otro imaginado» al «otro conocido» las películas tienden a presentar una imagen contrastante. En efecto, ya sea porque los personajes tienen alguna relación con el narcotráfico o porque se dedican a otro tipo de actividades, cuando en estas películas vemos a los colombianos en otros países a casi todos los encontramos distantes de la cultura local y de las personas oriundas del lugar. En casi todas las películas la imagen de los colombianos es la de personas que no entran en diálogo con los otros. Al respecto es pertinente recordar a Zygmunt Bauman cuando analiza las comunidades que se guarecen para protegerse de los extraños, pues vista así "comunidad significa mismidad, en tanto que «mismidad» significa la ausencia del Otro, especialmente de otro obstinadamente diferente" [2001b: 137]. Y esta es la tendencia de la representación de los colombianos en el exterior. Si no ensimismada, aparece como una comunidad aislada. Un gueto, añade Bauman citando a Loïc Wacquant, "combina el confinamiento espacial con el social” [2001b: 137]. Así se ven los personajes colombianos: replegados en una especie de gueto que se abre eventualmente. Y cuando se abre, ocurre sobre todo para dar acceso a aquellos que resultan menos extraños porque hablan la misma lengua.

Muestra de lo anterior está en Paraíso travel donde los colombianos o están con sus paisanos o excepcionalmente con otros latinos: Giovani, el puertorriqueño empleado del restaurante, y Milagros, la mexicana que se hace amante de Marlon. Marlon, incluso, teme porque es extranjero. “¿Cómo me quito este miedo?”, le pregunta a su auxiliador Hernando, y la respuesta que recibe es que "es cuestión de tiempo. Los inmigrantes llevamos el miedo y la incertidumbre adentro. Creemos que siempre hay alguien persiguiéndonos”. En María llena eres de gracia María sólo interactúa con colombianos: con los matones que la reciben en Nueva York y con Carla y su círculo. En ambas películas, por lo demás, buena parte de las acciones transcurren en Queens, el «barrio colombiano» en Nueva York. En El séptimo cielo Joselito sólo se relaciona con colombianos y dominicanos. A Mario, su hermano, le dice que su novia pertenece a otro mundo porque ella es estadounidense. En El arriero la relación entre Ancízar e Iñaki no va más allá de un vínculo instrumental por parte del español. Por lo demás, Ancízar siempre se rodea de sus mujeres colombianas o cuanto más se apoya en Roger, su confidente barranquillero.

Como se advierte, es por el trabajo o por las relaciones afectivas que los colombianos se rodean de otros colombianos, en su defecto de otros latinos y excepcionalmente de un nativo del país donde viven. Los colombianos en el exterior son representados como un colectivo con unos límites bastante fijos. La demarcación de espacios públicos y privados con símbolos como la bandera y el nombre del país - como sucede con la habitación de Joselito en El séptimo cielo, o los restaurantes de Paraíso travel y María llena eres de gracia - opera un traslado simbólico de su ámbito nacional al territorio extranjero. Por fuera de su «territorio natural», los miembros de la comunidad nacional 
tratan de recuperar y de conservar su unidad y su cohesión imaginarias. Lejos del país de origen, el anhelo del calor de la comunidad se traduce en nostalgia, en nombrar lo nuevo o desconocido con nombres provenientes de casa.

\subsection{Oficios de mujeres y de hombres}

Cuando las películas se analizan desde la perspectiva de la representación de los géneros retornamos al universo de la economía. Es sobre todo en las actividades que realizan los personajes, tanto en el ámbito público como en el privado, donde se configuran las imágenes de lo femenino y lo masculino.

Y en un contexto donde la pobreza y el desempleo se exponen como justificaciones de las más diversas conductas, las condiciones económicas también son utilizadas para justificar la venta o la explotación del cuerpo femenino. La expresión más evidente de esto es la prostitución, que es un tópico acerca del trabajo de las mujeres colombianas en el exterior.

Las muestras más patentes de ese estereotipo son la Caleña y Reina en Paraíso travel. En el caso de la Caleña la estereotipia es mayor: el lugar común que asocia la mujer caleña con el sexo fácil y la prostitución, y la mujer colombiana que busca trabajo en el exterior como prostituta. Yo encontré trabajo apenas llegué, le dice la Caleña con su marcado acento a Marlon cuando se reencuentran en un club de Nueva York en el que ella se contorsiona casi desnuda. Reina, por su parte, utiliza su cuerpo como instrumento para manipular a Marlon. Con ella, en mi opinión, no es el personaje masculino el que objetiva el cuerpo femenino. La imagen más redundante de la mujer que convierte su cuerpo en mercancía la vemos cuando Reina extrae de debajo de su falda de colegiala las fotografías de Nueva York y cuando se frota la entrepierna con los dólares robados. De Reina, sugiere la película, qué más se podía esperar: al final la vemos trabajando como prostituta en una avenida de Atlanta.

La cosificación del cuerpo femenino toca un extremo con el tráfico de drogas. María, Blanca y Lucy en María llena eres de gracia, Lucía en El arriero y Rosalba en El trato alquilan sus cuerpos para transportar cocaína. En María llena eres de gracia Javier sólo contrata mujeres para que hagan de mulas. Literalmente, las convierte en maletas vivas. Por encima de cualquier consideración, sus cuerpos son simplemente el continente de un producto que debe llegar a un destino. Una de las imágenes más crudas del cuerpo de la mujer colombiana reducido a objeto es la de María tendida en una camilla mientras Javier, con frialdad, le masajea el abdomen para acomodar las cápsulas y liberar espacio para las que ella no ha ingerido. En los momentos de la violencia más explícita, Lucy en María llena eres de gracia y una mula anónima en El arriero son destripadas por los narcotraficantes para recuperar la droga, tras lo cual los cuerpos son desechados.

Otra imagen es la de la mujer abnegada, adscrita al mundo de la familia, a la cocina y a los hijos. El tópico de la madre entregada a los hijos, al marido y a mantener el orden del hogar está en El séptimo cielo y en Paraíso travel. En efecto, la madre y la abuela de Joselito ocupan el centro del hogar. La madre, además de trabajar por fuera lo hace en la casa. La madre de Marlon es un personaje subordinado a la autoridad del padre, pero es con ella que Marlon se comunica desde Nueva York.Y en esa ciudad Marlon encuentra la imagen sustituta de su madre en Patricia, su protectora. Esta imagen sólo la desdibuja, aunque no la destruye totalmente, Virginia en El arriero. Ella, más que rehusarse a ser madre — lo que busca decididamente en un momento de la historia_-, cuando decide abortar pretende vengarse de Ancízar.

Por lo que respecta a la representación de lo masculino los hombres aparecen vinculados, sobre todo, a posiciones de mando, a la posesión sexual, a la mentira y a la ejecución de actividades violentas y brutales. El narcotráfico es un mundo de hombres. Las cabezas del negocio, los que trafican 
soñado y buscado por algunos personajes colombianos supuestamente para mejorar su situación: un país de traficantes y delincuentes. De ahí que estas imágenes contrastan la idealización de los otros países como lugares de fantasía con los valores de los extranjeros con quienes interactúan los colombianos. Estas alteridades, consideradas así, resultan ser una homología, sino un círculo vicioso. Sin duda, aunque tomando un camino incierto en María llena eres de gracia María es la única que rompe esta circularidad.

Por otro lado, en las películas encontramos referentes espaciales que identifican ciudades como Nueva York, Madrid o Londres. Sin embargo, entre los tópicos de las fotografías de postal se insertan imágenes de las ciudades marginales, delictivas o fraudulentas habitadas o transitadas por colombianos y en algunos casos por ciudadanos oriundos de allí. Y por este camino hallamos que en las relaciones que los colombianos establecen con sujetos de otros países los nacionales ocupan posiciones subordinadas, son marginales en las sociedades y las culturas extranjeras, y en algunos casos son también delincuentes. Así, en El arriero España y Madrid son territorio de drogas. Iñaki y la red de distribuidores son el correlato de Ancízar y su mundo colombiano. Cecil, el director inglés en El trato, es tan oportunista e inescrupuloso como los colombianos John María y Rosalba. En Paraíso travel, en María llena eres de gracia y en El séptimo cielo Nueva York es una mole de seres anónimos, acero y hormigón que explota y se sirve de los inmigrantes ilegales.

Las películas, no obstante, dejan ver algunas diferencias entre los colombianos y los ciudadanos de otros países cuando se relacionan por el tema de las drogas. Los personajes de otros países poco o nada pierden. En todas, los presos y los muertos a balazos o destripados son colombianos.

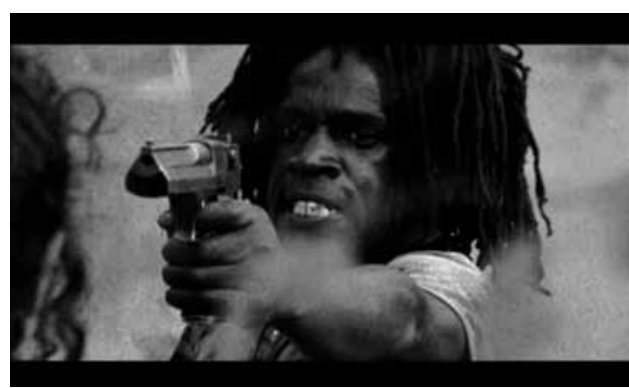

\subsection{Los colombianos según los «otros»}

Las drogas también son un lugar común cuando los personajes de otros países se refieren a los colombianos. Así, en El séptimo cielo, un indigente norteamericano pregunta a Joselito de dónde es (Joselito es blanco, de cabello oscuro, interpretado por un actor español), y cuando él responde que de Colombia el otro replica: “¿Tiene de ese polvo mágico?” Igualmente, cuando dos policías interrogan a Joselito por el hecho de ser colombiano y de concurrir al bar Séptimo cielo, el cual es regido por el colombiano Fernando Ortiz, los agentes presumen que Joselito debería tener conexiones con un cartel de drogas.

La asociación de la nacionalidad colombiana con el tráfico de narcóticos también es automática en María llena eres de gracia. Cuando María arriba al aeropuerto de Nueva York, apenas recoge su equipaje un oficial la aborda y, tras revisar su pasaporte y su billete de avión, la somete —al igual que a otros colombianos - a una pesquisa por sospecha de tráfico de drogas.

En El colombian dream la opinión de un extranjero sobre Colombia se da como un dato suelto. La opinión corre por cuenta de una española, quien a partir de una situación particular construye un juicio general. El personaje, una secuestrada de quien no se sabe nada, cuando es liberada dice: "Qué manía tenéis en este puto país de no hacer las cosas como se debe".

De las películas vistas la que configura su trama alrededor de un juicio explícito sobre Colombia y los colombianos es El trato. Parte de su trama pretende ironizar con el espectáculo que muchos medios internacionales y periodistas locales a su servicio crean alrededor de lo que acontece en Colombia. El trato discurre en parte sobre un falso documental dirigido por un inglés, quien busca una noticia sensacionalista que impacte y se venda en Inglaterra .La nota amarillista la pone la historia de una mula que, arriesgando su vida, sirve para llevar droga a las escuelas de Londres. Pero la falsa mula es deportada: “¿Londres?Yo no alcancé a vislumbrar cómo era Londres. Al llegar, apenas vieron mi pasaporte nuevecito un par de policías me llevaron a una sala donde me empelotaron”, dice el personaje. 


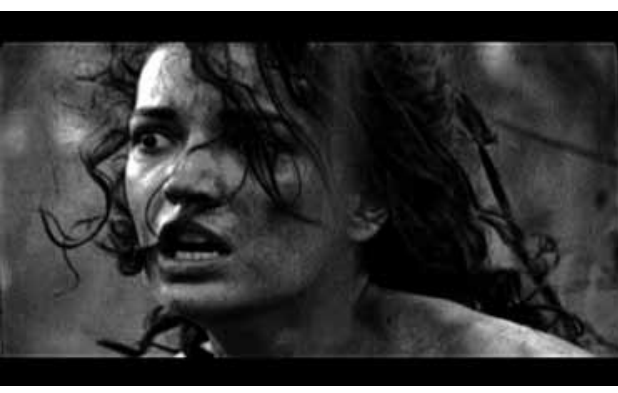

Los personajes españoles de El arriero agregan otros tantos juicios sobre Colombia y los colombianos. Iñaki, alguna vez mentor y luego socio del arriero Ancízar López, con uno de sus comentarios establece una relación entre el pasado y el presente. Cuando Iñaki recibe del arriero un cargamento de droga, dice: "Mientras tanto nosotros... como en la época del tanto monta. Vosotros de arrieros, y nosotros comiéndonos el pastel”. Es decir, hoy como ayer las ganancias se quedan aquí. Otro tópico sobre los colombianos corre por cuenta de los camellos de Madrid. Cuando entran en contacto con Ancízar, presentado por Iñaki, ellos comentan: "Así que colombiano, ¿no? A esta gente hay que tenerle mucho respeto, que es muy chunga para el tema de los negocios”. Y el otro: "Claro, pa' matar los colombianos y punto". La cosa no cambia mucho cuando Iñaki introduce a Ancízar con un extremeño: "Mira, éste es Ancízar López, colombiano. Va a ser tu contacto a partir de ahora”. Ancízar tiende la mano y el extremeño, sin aceptar el saludo, repone: “¿Pero qué coño es esto, Iñaki? O sea que ahora me entenderé con un puto colombiano y encima negro”. Y después, para seguir con los lugares comunes, cuando una mujer distribuidora de drogas conoce al Arriero en Madrid define el «allá» de ustedes como una imagen pobre de nuestro «aquí»: "Yo he estado en Medellín y me encanta. Es una ciudad impresionante. Así como del Mediterráneo, pero de pobre”.

Por último, encontramos otro motivo en El séptimo cielo. En esta película vemos el rechazo de un colombiano por parte de una familia estadounidense. Se trata de Mario, el hermano de Joselito. Los padres de Susan, su novia, no aceptan la relación entre ellos porque Mario es un "spic" ${ }^{13}$. Menos, entonces, aceptarán que ella tenga un hijo con él. Por eso, Mario piensa que necesita dinero para cambiar su imagen. Él afirma que no tendrá un hijo "spic". Y Susan lo corrige: nada de un hijo "spic", el de ellos será "medio spic". Es decir, hasta la novia de Mario lo encasilla a él y a su hijo dentro de ese estereotipo.

\section{Conclusiones}

Las imágenes de los colombianos en el exterior se construyen con elementos que marcan una tendencia. La marginalidad, la ilegalidad, la precariedad, la violencia y el narcotráfico son referencias constantes asociadas tanto con hombres como con mujeres. Estas imágenes muestran a los colombianos como un mal o una amenaza para las comunidades a las cuales llegan. Sin embargo, como advierte Bauman, los extraños también son «tolerados» mientras se mantengan a determinada distancia y mientras se ocupen de ciertas actividades. De ahí que los colombianos sean presentados como piezas útiles en los marcos sociales y culturales extranjeros en los cuales se insertan, y que a la vez las películas representen esas culturas y esas sociedades como medios que se sirven y se benefician de nuestros migrantes. Unas imágenes constantes son, pues, las de los colombianos realizando el trabajo descartado por los naturales del lugar o actividades ilegales requeridas por un sector de esas sociedades. O en otros casos, los colombianos, o más exactamente las mujeres colombianas son proveedoras de experiencias placenteras y fugaces demandadas por los habitantes de esos espacios.

Si bien se ha descrito una tendencia mayor, es preciso anotar que las imágenes de los colombianos en el exterior también muestran una tendencia que, aun compartiendo algunos rasgos con la anterior, no está asociada con el narcotráfico y la violencia. Aunque en las condiciones de vida de algunos personajes se aprecia la marginalidad, la estancia ilegal en el exterior y la precariedad laboral, en ellos se lee también una distancia clara con la brutalidad y el tráfico de drogas. En algunos, incluso, se aprecia que con el paso del tiempo se alcanza cierta estabilidad y autonomía, como ocurre con Carla y su familia en María llena eres de gracia y Patricia y Pastor en Paraíso travel. 
En resumen, la idealización de otros países, ya sea afincada en la imaginería de la prosperidad o en la iconografía de las postales, contrasta con una imagen común del inmigrante colombiano. En estas películas se detecta la reproducción de una serie de prejuicios y estereotipos, de imágenes maniqueas que no dan cuenta de relatos plurales, que no permiten pensar la complejidad de ser inmigrante ni de una globalización que a la vez que aglomera separa y atomiza. La representación es simplificada y redundante: una inmigración asociada con la ilegalidad, la marginalidad, la explotación, la delincuencia, la muerte, la prostitución, la violencia, el hacinamiento y, en medio de todas las calamidades, la esperanza. Por esto los personajes y las situaciones reiterados: putas, traficantes, rebuscadores, explotados. Esta carga negativa la aligera el calor familiar, ya sea que se haga sentir in situ o a la distancia, y con algunas dosis de solidaridad alimentada por la condición de compartir la nacionalidad. Además, la imagen de los colombianos es la de un grupo integrado, si acaso, en el mundo productivo pero resguardado dentro de los límites de su lengua y de sus costumbres. En este sentido, de acuerdo con estas ficciones esas formas de vida en el exterior hacen más evidente el carácter imaginario de la comunidad nacional ${ }^{14}$.

Tras describir el modo como el cine y los distintos medios intervienen en los procesos de formación de las identidades en un orden de "multimedios y multicontextualidad”, García Canclini afirma que "dinamizada por este proceso [...] Al ser un relato que reconstruimos incesantemente, que reconstruimos con los otros, la identidad es también una coproducción” [1995: 114]. En el caso de lo expuesto aquí, no es que las películas decreten que los colombianos «son esto»o «son así». Las películas son relatos de país, proporcionan imágenes para la elaboración de los distintos relatos que construyen los distintos sectores de la sociedad. Ellas representan modos posibles de ser y, por lo tanto, de los colombianos pensarse, de pensar sobre otros y de que otros piensen sobre ellos. En la comunicación de este ser posible se pone en juego la creación de imágenes compartidas que intervienen en la estructuración de creencias y en el ordenamiento del espacio histórico. Esta es una manera de entender lo que García Canclini llama “coproducción”.

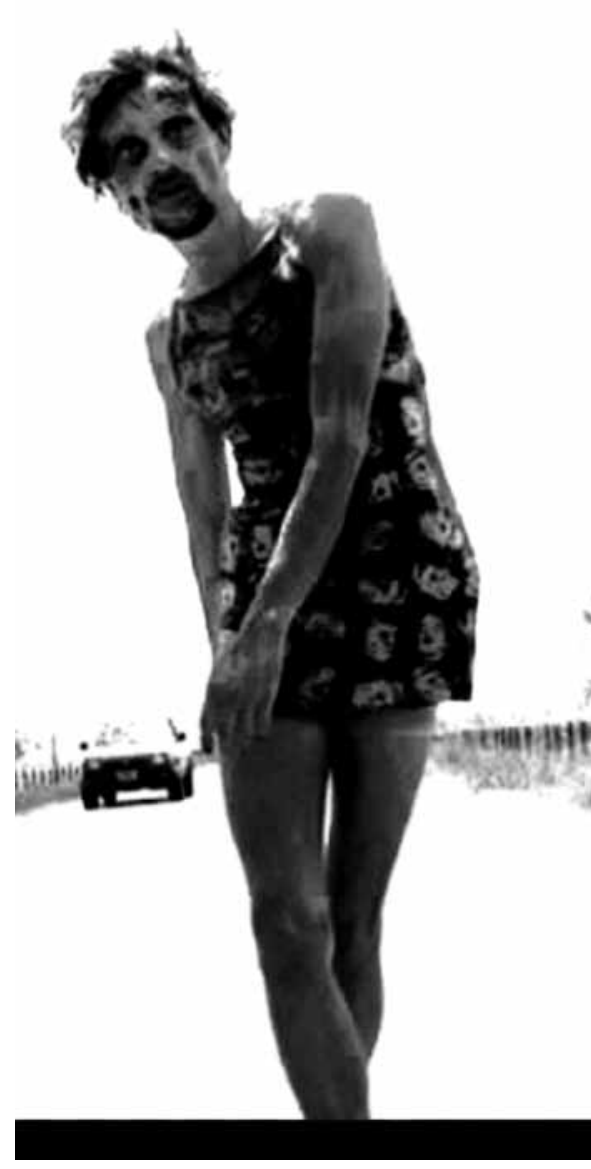

Sin embargo, cuando los discursos que sirven para construir formas de la identidad son asociados a sus enunciadores, es decir cuando la formación de las identidades se relaciona con las fuentes del discurso, cabe preguntarse por las lógicas desde las cuales se están configurando estas imágenes. O sea, por las lógicas con las cuales se establece la "coproducción". No podemos olvidar que el contexto en el cual se han producido y realizado estas películas es el de una economía globalizada, «multimedial»según García Canclini, y que el cine, por su carácter industrial, mantiene una relación compleja con ese marco. El mismo García Canclini advierte que "esta coproducción se realiza en condiciones desiguales entre los variados actores y poderes que intervienen en ella” [1995: 114]. Entonces, cuando encontramos que una constante formal y temática en la mayoría de las películas analizadas es que apelan a personajes y situaciones estereotipados y a formas narrativas convertidas en esquemas, la lógica que emerge enseguida es una que abreva de otras narrativas mediáticas y que es deudora del mercado.Y no es que las formas narrativas tradicionales estén vedadas, sino que con su uso frecuente se traducen en moldes para vaciar en ellos los mismos ingredientes aunque sean mezclados en un orden distinto.

Una conclusión evidente de lo visto, por lo tanto, es que el conjunto de imágenes detectado en las películas, que de uno u otro modo coadyuva a la construcción de discursos identitarios, llega al público con la marca de la industria. La industria, el mercado y sus fórmulas, con los cuales pactan los estamentos públicos cuando diseñan políticas de fomento para el sector y cuando apoyan los proyectos cinematográficos, se convierten en factores que condicionan y terminan haciendo parte de las construcciones discursivas que soportan los relatos identitarios.

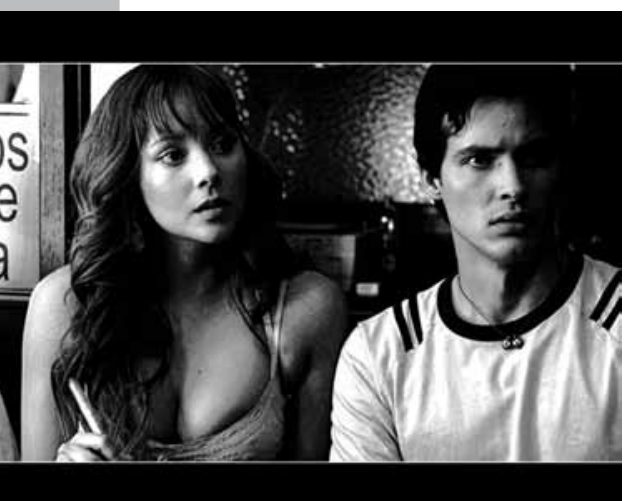




\section{Notas:}

1. La investigación fue realizada entre septiembre de 2009 y junio de 2010 en la Escuela de Comunicación Social de la Universidad del Valle y está adscrita al Grupo de investigación en sonido, imagen y escritura audiovisual Caligari.

2. Es importante recordar que en nuestro país ha aumentado el flujo de emigrantes en los últimos años. Según datos del Dane - provenientes del último censo nacional realizado en el año 2005 y reproducidos por el Ministerio de Relaciones Exterioresla evolución de emigrantes colombianos entre 1960 y 2005 registró el siguiente crecimiento: 1960, 117.377; 1970, 263.841; $1980,710.372 ; 1990,893.902 ; 2000,1.392 .508 ; 2005,3.378 .345$. Aunque no se ha podido acceder a un dato actualizado a la fecha sobre el número de colombianos con residencia permanente en el exterior, es de prever que la tendencia se ha conservado. Resulta, entonces, difícil dudar de que para quienes se convierten en inmigrantes su nueva condición no los conduzca a comparar los referentes adoptados como propios y a impregnarse de aquellos que encuentran en los territorios a los cuales llegan. Véase www. cancilleria.gov.co

${ }^{3 .}$ De manera similar, Miquel Alsina apunta que a pesar de su puesta en cuestión "el concepto de identidad tiene el inevitable sentido de unidad concreta y coherente. La identidad se nos presenta como lo que es por sí misma. Por el contrario, las identificaciones nos remiten al polimorfismo del ser y a su permanente reconstrucción” [1996: 44].

4. Es pertinente advertir, no obstante, que si bien esta manera de entender la identidad es hoy de uso corriente a ella no le faltan críticas. En un artículo polémico, Jorge Orlando Melo rechaza, en primer lugar, que se siga usando el término «identidad» por las dificultades que implica dotarlo de contenido y, más aún, por el uso que hacen de él agentes relacionados con algún tipo de poder para legitimar visiones unilaterales de lo que identificaría a un grupo social. En consecuencia, Melo propone lo siguiente: “en vez de seguir tratando de redefinir la identidad para evitar los rasgos fastidiosos y las aristas molestas del concepto, lo que ha llevado a un uso perfectamente informal, descuidado y arbitrario de esta palabra, es preferible abandonarla del todo y tratar de encontrar nuevas formas de definir la situación cultural del país y las relaciones entre sus procesos culturales" [2006: S.P.]. Sobre la concepción teórica de la identidad que se sigue aquí, Melo señala, en segundo lugar, que es una suerte de callejón sin salida atrapada en sus premisas. Melo describe esta concepción como “《invencionista», «constructivista» o «construccionista»” [2006: S.P.], en la cual “lo único que constituye la identidad es el discurso por el cual sus miembros se reconocen como miembros de esa comunidad. Pero el contenido de ese discurso, hay que recordarlo, es relativamente arbitrario e indeterminable” [2006: S.P.]. Por lo tanto, agrega, “está claro que esta "identidad" es una propuesta arbitraria, una propuesta política, una ideología, algo que podemos aceptar o rechazar" [2006: S.P.]. En conclusión, anota, "la "identidad discursiva" o construida no logra evitar ser una propuesta más o menos abusiva y arbitraria a la que se induce a la población, o un error compartido masivamente” [2006: S.P.]. Contra esta posición, cabe recordar precisamente lo que expone Stuart Hall: la identidad, entendida como discurso, no es ajena a la intencionalidad del hablante. Ella corresponde a la toma de una posición estratégica: tras el discurso que nombra hay alguien que enuncia, hay una intencionalidad. Y para esta perspectiva del estudio de las identidades resulta de interés reconocer esas posiciones.

5. Stuart Hall lo dice así: "En el lenguaje del sentido común, la identificación se construye sobre la base del reconocimiento de algún origen común o unas características compartidas con otra persona o grupo o con un ideal, y con el vallado natural de la solidaridad y la lealtad establecidas sobre este fundamento. En contraste con el «naturalismo» de esta definición, el enfoque discursivo ve la identificación como una construcción, un proceso nunca terminado: siempre «en proceso». No está determinado, en el sentido de que siempre es posible «ganarlo» o «perderlo», sostenerlo o abandonarlo. Aunque no carece de condiciones determinadas de existencia, que incluyen los recursos materiales y simbólicos necesarios para sostenerla, la identificación es en definitiva condicional y se afinca en la contingencia” [1996: 15].

6. Desde la lingüística, Emile Benveniste [1966] había llamado la atención al examinar la naturaleza de los pronombres personales sobre la correlación entre el «yo» y el «tú». Recordemos que Benveniste plantea que los pronombres son instancias del discurso, cobran sentido cuando son actualizados en un acto de lenguaje: yo hace referencia a quien dice «yo», y «yo»—quien habla- se utiliza para dirigirse y a la vez diferenciarse de otro, de un «tú»_ quien escucha_- «Yo», pues, descubre una posición discursiva relativa. En el caso del estudio de la identidad, este postulado permite observar que una instancia de enunciación determinada se manifiesta en relación con otro. Dicho de otra manera, cuando la configuración y la apropiación de un discurso acontecen un sujeto adquiere presencia, adopta una posición discursiva y construye la realidad en relación con un «otro». Por esta razón, se comprende que Hall sostenga que "[e]l concepto de identidad aquí desplegado no es, por lo tanto, esencialista, sino estratégico y posicional” 
[1996: 17]. Benveniste lo expresa así: “¿Cuál es, pues, la «realidad» a la que se refiere yo o tú? Tan sólo una «realidad de discurso» [...]. Yo no puede ser definido más que en términos de «locución», no en términos de objetos, como lo es un signo nominal. [...] La definición puede entonces ser precisada así: yo es el «individuo que enuncia la presente instancia de discurso que contiene la instancia lingüística yo». Por consiguiente, introduciendo la situación de «alocución», se obtiene una definición simétrica para tú, como «el individuo al que se dirige la alocución en la presente instancia de discurso que contiene la instancia lingüística tú». Estas definiciones apuntan a yo y tú como categoría del lenguaje y se refieren a su posición en el lenguaje” [1966: 1].

7. En sentido similar, Bauman asevera que "los extraños son las personas que no encajan en el mapa cognitivo, moral o estético" [1997: 27]. Dicho de otro modo, los extraños son personas que desbordan el sistema de valores creado por una comunidad, la cual mediante prejuicios reafirma su imagen estableciendo barreras y marcando diferencias con los otros. Por este motivo, afirman Blanck-Cereijido y Yankelevich, el prejuicio es "la parte inconsciente de la ideología de una sociedad, [es el] conjunto de sentimientos, juicios y actitudes que provocan y justifican medidas discriminatorias, separación, segregación, y explotación de un grupo por otro" [2003: 24].

${ }^{8 .}$ El concepto de estereotipo ha sido analizado y definido desde disciplinas como la retórica, la semiótica, la publicidad, la sociocrítica, la teoría literaria y la sicología social. Amossy y Herschberg [1997] hacen un recuento de algunos modos como ha sido definido este concepto. Entre otras definiciones, estos autores incluyen esta: "Un estereotipo es una creencia que no se da como hipótesis confirmada por pruebas, sino más bien considerada, de manera entera o parcialmente equivocada, como un hecho dado" [Jahoda, 1964, en Amossy y Herschberg, 1997: 32]. Sobre los estereotipos también remito a González Catalina, 1997.

La misma Nora Moll destaca que la imagología "puede entenderse como una de las formas de indagación más «concretas» de la aproximación a la alteridad. [...] La imagología y los estudios interculturales, por su capacidad de centrarse en cuestiones históricoculturales, políticas y sociales relacionadas con el contacto entre distintos pueblos y culturas, pueden revestir hoy una gran importancia y tener interesantes aplicaciones" [2002: 347].

10. A la película Dr. alemán no se hace referencia en este artículo porque ella trata sobre la presencia de un extranjero en Colombia y este texto discurre sobre imágenes de la inmigración colombiana.

11. Cuando se observa el listado de los países que en las películas parecen tener aquello que le falta a Colombia, a juzgar por las estadísticas sobre migración del Ministerio de Relaciones Exteriores no debe parecer extraño que Estados Unidos y España sean considerados en las ficciones como países ideales, o por lo menos mejores que el nuestro. Es hacia allá hacia donde han migrado más colombianos en los últimos años. En efecto, de acuerdo con el último censo de población realizado en el año 2005, el Ministerio de Relaciones Exteriores reporta que los "destinos elegidos por los migrantes colombianos, según el DANE, son: Estados Unidos $(34,6 \%)$, España $(23,1 \%)$, Venezuela $(20,0 \%)$, Ecuador $(3,1 \%)$, Canadá $(2,0 \%)$, Panamá $(1,4 \%)$, México $(1,1 \%)$, Costa Rica $(1,1 \%)$ y con un porcentaje mínimo Australia, Perú y Bolivia” [http://www.cancilleria.gov.co].

12. Según el director y guionista Francisco Norden, la idea del falso documental de El trato tiene origen en una información publicada por el diario inglés The Guardian, en la cual denunció una entrevista falsa realizada por unos cineastas ingleses con un narcotraficante colombiano. En una entrevista con CiudadViva, medio del Instituto Distrital de Cultura y Turismo de Bogotá, en julio de 2006 Norden declaró lo siguiente: "Lo que me despertó la curiosidad fue una noticia a ocho columnas del influyente diario londinense, The Guardian, en donde se denunciaba cómo una empresa filmadora engañó a casi cuatro millones de televidentes. Como no pudieron filmar lo que querían, lo inventaron” [http://www.ciudadviva.gov.co/julio06/magazine/4/index.php].

La palabra "spic" es un término despectivo utilizado en Estados Unidos para referirse a inmigrantes de habla castellana o portuguesa, en especial de origen o ascendencia latinoamericano. Según la página web Urban dictionary "Spic" significa "A highly offensive term referring to a Spanish-speaking person from Mexico, Central or South America, Spain, or Portugal", "racial slur for people of Latino descent". Cfr. http://www.urbandictionary.com/define.php?term=spic.

Según Benedict Anderson, la nación es una "comunidad política imaginada”: "Es imaginada porque aun los miembros de la nación más pequeña no conocerán jamás a la mayoría de sus compatriotas, no los verán ni oirán jamás hablar de ellos, pero en la mente de cada uno vive la imagen de su comunión" [1983: 23]. Para Anderson, además, la nación "se imagina como comunidad porque, independientemente de la desigualdad y la explotación que en efecto puedan prevalecer en cada caso, la nación se concibe siempre como un compañerismo profundo, horizontal” [1983: 25]. 


\section{Bibliografía}

Amossy Ruth, Herschberg Anne [1997]. Estereotipos y clichés. Buenos Aires: Eudeba, 2005. Aínsa Fernando [1986]. Identidad cultural de Iberoamérica en su narrativa. Madrid: Gredos. Alsina Miquel Rodrigo [1996]. “Minorías étnicas, identidades y medios de comunicación”. En Signo y pensamiento. Bogotá: Vol. XV, N²9, pp. 39-48, jul-dic.

Anderson Benedict [1983]. Comunidades imaginadas. México: FCE: 1993.

Aumont Jacques, Marie Michel [1988]. Análisis del film. Barcelona: Paidós, 1990.

Bauman Zygmunt [1997]. La posmodernidad y sus descontentos. Madrid: Akal, 2001.

Bauman Zygmunt [1999]. En busca de la política. Buenos Aires: FCE, 2001.

Bauman Zygmunt [2001a]. La sociedad individualizada. Madrid: Cátedra.

Bauman Zygmunt [2001b]. Comunidad: en busca de seguridad en un mundo hostil. Madrid: Siglo XXI, 2003.

Blanck-Cereijido Fanny [2003]. El otro, el extranjero. Madrid: Libros de El Zarzal.

García Canclini Néstor [1995]. Consumidores y ciudadanos. Conflictos multiculturales de la globalización. México: Grijalbo.

González Catalina [1997]. "Identidad, alteridad y comunicación: definiciones y relaciones". En Signo y Pensamiento. Bogotá. Vol. XVI, No. 30, pp. 77-84, ene-jun.

Hall Stuart [1996]. "Quién necesita identidad”. En Hall Stuart, Du Gay Paul (comps.) [1996]. Cuestiones de identidad cultural. Buenos Aires: Amorrortu, 2003: 13-39.

Martín Barbero J. [2001]. "Colombia: ausencia de relato y desubicaciones de lo nacional”, pp. 1729. En Barbero Martín J. (comp.) [2001]. Imaginarios de nación. Pensar en medio de la tormenta. Bogotá: Mincultura, pp. 17-29.

Moll Nora [2002]. La imagología: definición y terminología. En Gnisci Armando [2002]. Introducción a la literatura comparada. Barcelona: Crítica, pp. 347-389.

Sennett Richard [1978]. El declive del hombre público. Buenos Aires: Península.

Suárez Juana [2009]. Cinembargo Colombia. Ensayos críticos sobre cine y cultura. Santiago de Cali: Universidad del Valle.

White Hayden [1973]. Metahistoria: la imaginación histórica en el siglo XIX. México: FCE, 1992. White Hayden [2003]. El texto histórico como artefacto literario. Barcelona: Paidós.

\section{Cibergrafía}

http: / / www.cancilleria.gov.co

Consulta en abril de 2010

Melo Jorge Orlando [2006]. “Contra la identidad”. En El Malpensante, $N^{\circ}$ 74, nov-dic 2006 http: / / www.elmalpensante.com/index.php?doc $=$ display_contenido\&id $=359 \& p a g=7 \&$ size $=\mathrm{n}$ Consulta en enero de 2010

Benveniste Emile [1966]. Problemas de lingüística general. Madrid: Siglo XXI, 1991. http: / /www.upf.edu/materials/fhuma/oller/generes/tema2/lectures/ben_lanaturaleza.pdf Consulta en enero de 2010

http://www.ciudadviva.gov.co/julio06/magazine/4/index.php Consulta en abril de 2010

www.urbandictionary.com/define.php?term $=$ spic.

Consulta en marzo de 2010 